\title{
HIPK2 Gene
}

National Cancer Institute

\section{Source}

National Cancer Institute. HIPK2 Gene. NCI Thesaurus. Code C102956.

This gene plays a role in the phosphorylation of transcription factors. 